\title{
Project Test Plan for Runoff and Erosion on Fine-Soil Barrier Surfaces and Rock-Covered Side Slopes
}

W. H. Walters

K. A. Hoover

L. L. Cadwell

June 1990

Prepared for the U.S. Department of Energy under Contract DE-AC06-76RLO 1830

Pacific Northwest Laboratory Operated for the U.S. Department of Energy by Battelle Memorial Institute 


\title{
DISCLAIMER
}

This report was prepared as an account of work sponsored by an agency of the United States Government. Neither the United States Government nor any agency thereof, nor Battelle Memorial Institute, nor any of their employees, makes any warranty, expressed or implied, or assumes any legal liability or responsibility for the accuracy, completeness, or usefuiness of any information, apparatus, product, or process disclosed, or represents that its we would not infringe privately owned rights. Reference herein to any specific commercial product, process, or service by trade name, trademark, manufacturer, or otherwise, does not necessarily constitute or imply its endorsement, recommendation, or favoring by the United States Government or any agency thereof, or Battelle Memorial Institute. The views and opinions of authors expressed herein do not necessarily state or reflect those of the United States Government or any agency thereof.

\author{
PACIFIC NORTHWEST LABORATORY \\ operated by \\ BATTELLE MEMORIAL. INSTITUTE \\ for the \\ UNITED STATES DEPARTMENT OF ENERGY \\ under Contract DE-AC06-76RLO 1830
}

Printed in the United States of America

Available to DOE and DOE contractors form the

Office of Scienufic and Technical Information, P.O. Box 62, Oak Ridge, TN 37831; prices available from (615) 576-8401. FTS 626-8401.

Available to the public frem the National Technical Information Service,

U.S. Department of Commerce, 5285 Porl Royal Rd. Springficld, VA 22161.

NTIS Price Coxdes, Microfiche A01

Printed Copy

\begin{tabular}{cr}
\hline Price Code & Page Range \\
\hline A02 & $1-10$ \\
A03 & $11-50$ \\
A04 & $51-75$ \\
A05 & $76-100$ \\
A06 & $101-125$ \\
A07 & $126-150$ \\
A08 & $151-175$ \\
A09 & $176-200$ \\
A10 & $201-225$ \\
A11 & 226.250 \\
A12 & $251-275$ \\
A13 & $276-300$ \\
A14 & $301-325$
\end{tabular}

\begin{tabular}{cc}
\hline Price Code & Page Range \\
\hline A15 & $326-350$ \\
A16 & $351-375$ \\
A17 & $376-400$ \\
A18 & $401-425$ \\
A19 & $426-450$ \\
A20 & $451-475$ \\
A21 & $476-500$ \\
A22 & $501-525$ \\
A23 & $526-550$ \\
A24 & $551-575$ \\
A25 & $576-600$ \\
A99 & $601-U p$
\end{tabular}


PNL-6791

UC -403

PROJECT TEST PLAN FOR RUNOFF AND EROSION

ON FINE-SOIL BARRIER SURFACES AND

ROCK-COVERED SIDE SLOPES
W. H. Walters
K. A. Hoover
L. L. Cadwell

June 1990

Prepared for

the U.S. Department of Energy

under Contract DE-AC06-76RLO 1830

Pacific Northwest Laboratory

Richland, Washington 99352 


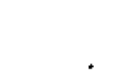




\section{SUMMARY}

This test plan was written by Pacific Northwest Laboratory (PNL) staff for the U.S. Department of Energy as part of the Hanford Protective Barriers Program on the Hanford Site, Richland, Washington. The program is a multitask cooperative effort between Westinghouse Hanford Company and PNL to investigate the ability of aboveground, mounded earthen and rock structures to isolate shallow-buried waste. The structures will consist of layered fine-grained soil and rock designed to direct the surface water and groundwater pathways away from the buried waste.

As part of the barrier soil-erosion task within the Protective Barriers Program, this report presents the experimental testing and work plan for investigating the effects of surface water runoff and erosion on the barrier mound's top surface and side slopes. The test plan also considers soil settlement and consolidation as it affects erosion and side slope stability. Under this task, recomnendations of barrier design criteria to minimize the impacts of precipitation on barrier soil erosion and overall stability for up to 10,000 years will be made.

The test plan describes the experimental testing begun in FY 1989 using a simple two-component system (soil and precipitation) to identify the basic erosional characteristics of McGee Ranch soil. Larger and more complex plot testing will occur in the following years. The added complexities will involve the effects of vegetation, animal burrowing (to be coordinated with other tasks), soil settlement, and slope stability. Testing and data analysis are scheduled for completion by the end of FY 1993. 


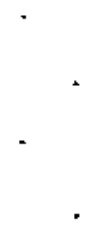




\section{CONTENTS}

SUMMARY ..............................

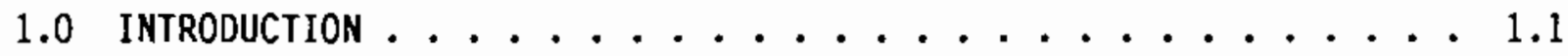

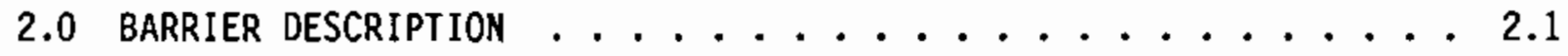

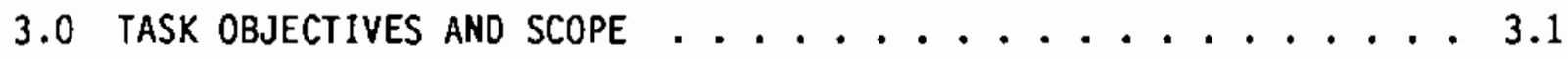

4.0 PROCESSES AFFECTING BARRIER STABILITY . . . . . . . . 4.1

4.1 RUNOFF-EROSION PROCESSES ................... 4.1

4.1 .1 Rainsplash ........................ 4.1

4.1 .2 Overland Runoff . . . . . . . . . . 4.1

4.2 PROCESSES SPECIFIC TO ROCK-ARMORED SIDE SLOPES $\ldots \ldots . \ldots$

4.3 EFFECTS OF SETTLEMENT ON BARRIER EROSION $\ldots \ldots \ldots . \ldots$

4.3.1 Differential Settlement ........... 4.3

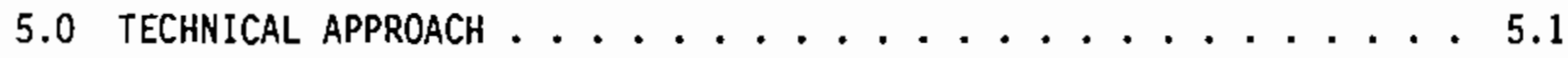

5.1 EXPERIMENTAL FIELD TESTING .................... 5.1

5.1 .1 McGee Ranch Soils ............ 5.2

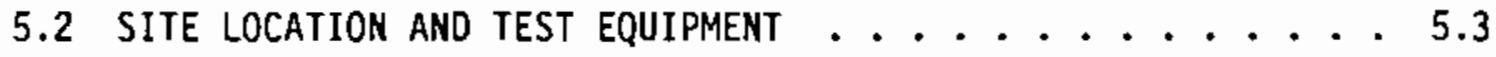

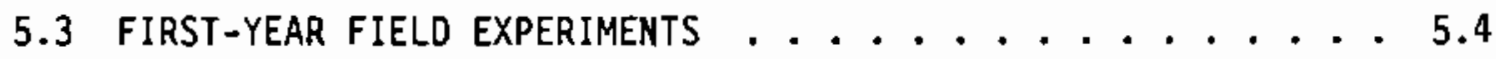

5.3.1 Experimental Design ........... 5.5

5.4 SECOND-YEAR WORK PLAN . . . . . . . . . . . . . 5.8

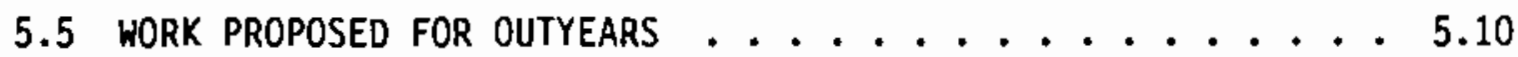

5.6 SCHEDULE AND ESTIMATED COSTS . . . . . . . . 5.11

6.0 SAFETY AND QUALITY ASSURANCE . . . . . . . . . . 6.1

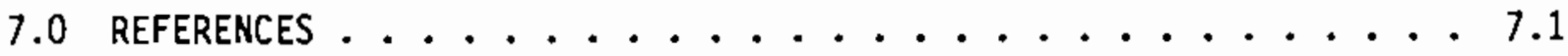

APPENDIX - NUMERICAL MODELING OF EROSION ............. A.1 


\section{FIGURES}

1 Location of the McGee Ranch Field Plot Studies on the Hanford Site .................. 2.2

2 Conceptual Design of Barrier System . . . . . . . . . 2.3

3 Plot Layout Configuration and Typical Plot Design . . . . . . 5.6

4 Plot Soil Compaction Scheme ............... 5.7

IABLE

1 Schedule and Costs per fiscal year ........... 5.2 


\subsection{INTRODUCTION}

Pacific Northwest Laboratory (PNL) and Westinghouse Hanford Company are working together to develop protective barriers to isolate near-surface radioactive waste. The purpose of the barriers is to protect defense wastes at the U.S. Department of Energy's (DOE) Hanford Site from infiltration of precipitation, biointrusion, and surficial erosion for up to 10,000 years without the need for long-term monitoring, maintenance, or institutional control. The barriers will be constructed of layered earth and rock material designed to direct surface and groundwater pathways away from the buried waste.

Because the barriers will have an earthen cover, soil erosion from rainfall-runoff and snownelt processes could remove significant quantities of soil and reduce the effectiveness of the cover. Deep gullying or sideslope destabilization and slumping as a result of surficial erosion could cause breaching of the barrier and direct exposure of the waste to infiltrating precipitation, animals, or humans. Less severe slope degradation could also decrease the effectiveness of the barrier merely by reducing the thickness of the available soil cover and allowing percolation of seasonal rainfall and snowmelt to reach the waste.

To address soil erosion as it applies to barrier design and long-term stability, a task designed to study this problem has been included in the Protective Barriers Program at PNL. The barrier soil-erosion task will investigate the ability of the soil cover and side slopes to resist the erosional and destabilizing processes from externally applied water (rain or snow). The study will include identification and field testing of the dominant processes contributing to erosion and barrier failure. The effects of rock mulches, vegetation cover on the top fine-grained soil surface, as well as the stability of rock armoring on the side slopes, will be evaluated. Some of the testing will include the effects of animal intrusion on barrier erosion, and these will be coordinated with other animal intrusion studies. The product of the study will be a quantitative assessment of the types and 
magnitudes of degradation expected to occur over the 10,000-year life of the barrier, and recommendations of barrier design criteria to minimize the impacts of overland flow and erosion.

This report contains seven sections. Sections 2.0 and 3.0 provide a description of a typical barrier and define study objectives, respectively. Section 4.0 describes the physical processes affecting barrier stability that are of concern in this study. Section 5.0 presents the experimental test plan, schedule, and costs to accomplish the stated objectives. Section 6.0 discusses safety and quality assurance, and Section 7.0 contains the 1 ist of references. The appendix provides a brief review of numerical modeling methods used to estimate soil erosion. 


\subsection{BARRIER DESCRIPTION}

The placement of earthen barriers over the shallow-burial radioactive waste sites at Hanford has been proposed as a method to isolate and protect the waste. The proposed barrier design consists of approximately $5 \mathrm{~m}$ of layered rock and earth material placed over, and extending some distance beyond, individual or clustered waste burial sites. The barriers will be roughly rectangular in shape with relatively flat tops. The top surfaces may be up to several thousands of square meters in area with a potential range of slopes between 0 and $1 \mathrm{~V}: 20 \mathrm{H}$. The side slopes, approximately $16 \mathrm{~m}$ in length, will be much steeper, with slopes of about $1 \mathrm{~V}: 3 \mathrm{H}$. The top $1.5 \mathrm{~m}$ of the barrier will consist of fine-grained soil from the McGee Ranch area located within the Hanford Site (Figure 1). This soil will store moisture above the waste and provide a suitable environment for the vegetation that will stabilize the surface and remove excess moisture through evapotranspiration. Rock mulch may be mixed into the fine soil as an erosion inhibitor.

Figure 2 is an early conceptual design proposed by Adams and Wing (1986) that illustrates the basic barrier configuration. Because barrier design is not final, the structural elements are expected to change. For example, the side slopes in Figure 2 are shown as a rock and fine soil mixture; however, other designs are being considered. The basic side slope will probably be constructed of soil covered with rock riprap with sand-gravel layers between the rock and soil.

The barriers will be subjected to hydrologic and erosional processes from rainfall-runoff and snowmelt. The top surface must resist water erosion and maintain sufficient moisture to support vegetation but, with the vegetation, prevent deep percolation into the waste. Loss of soil by water erosion will reduce the thickness of the soil cover and jeopardize its ability to store water and control percolation. The barrier's steep side slopes require rock protection against severe erosion. The critical problem in the case of the side slopes is the effect of moisture buildup on sideslope stability and the potential for long-term erosion of soil from within or beneath the rock cover. Further modification of the top and side slopes 
by animal burrowing and gradual settlement (causing surface cracking) may enhance infiltration, provide more direct pathways to the buried waste, and reduce the overall stability of the entire barrier mound.

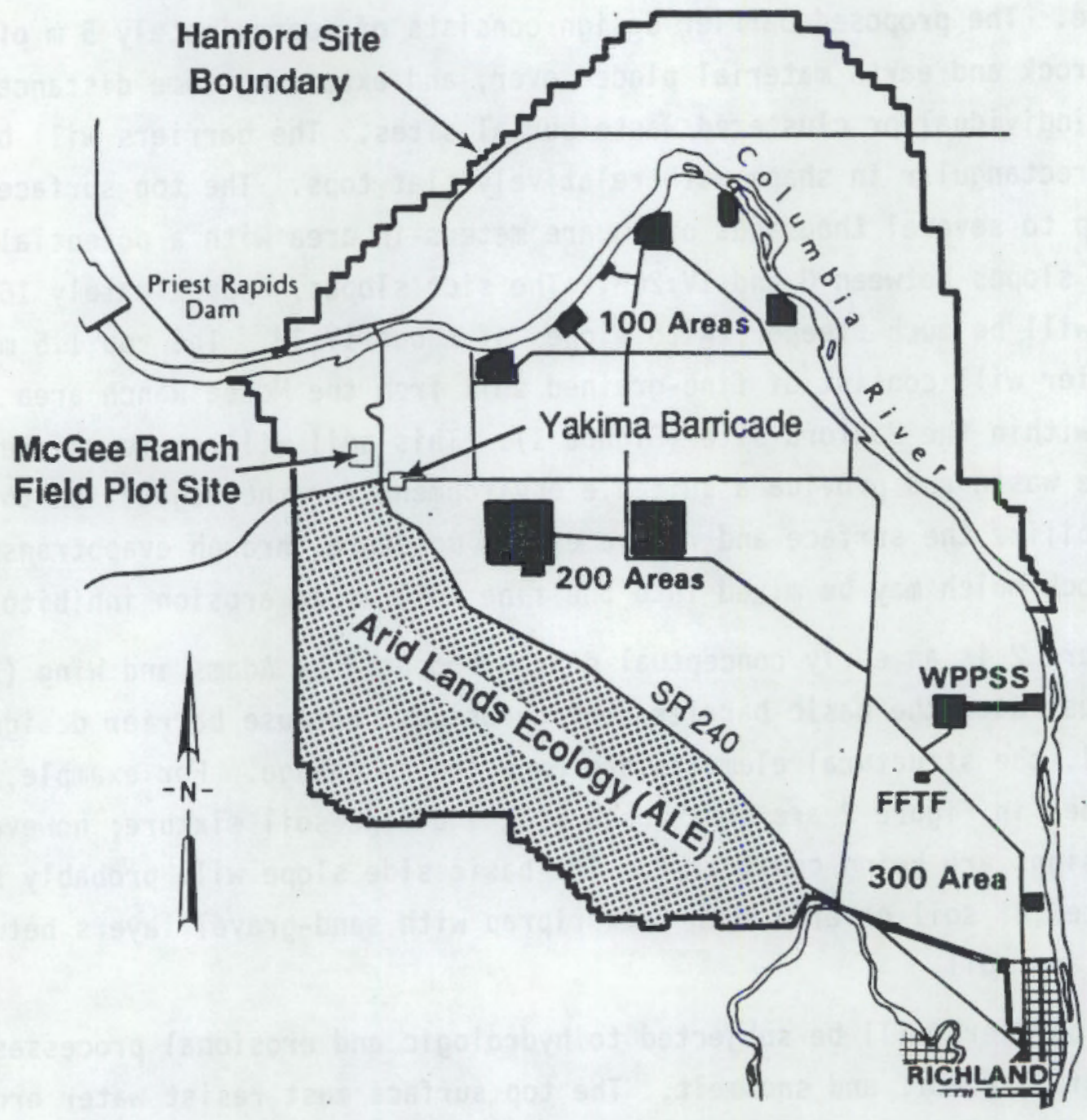

FIGURE 1. Location of the McGee Ranch Field Plot Studies on the Hanford Site 

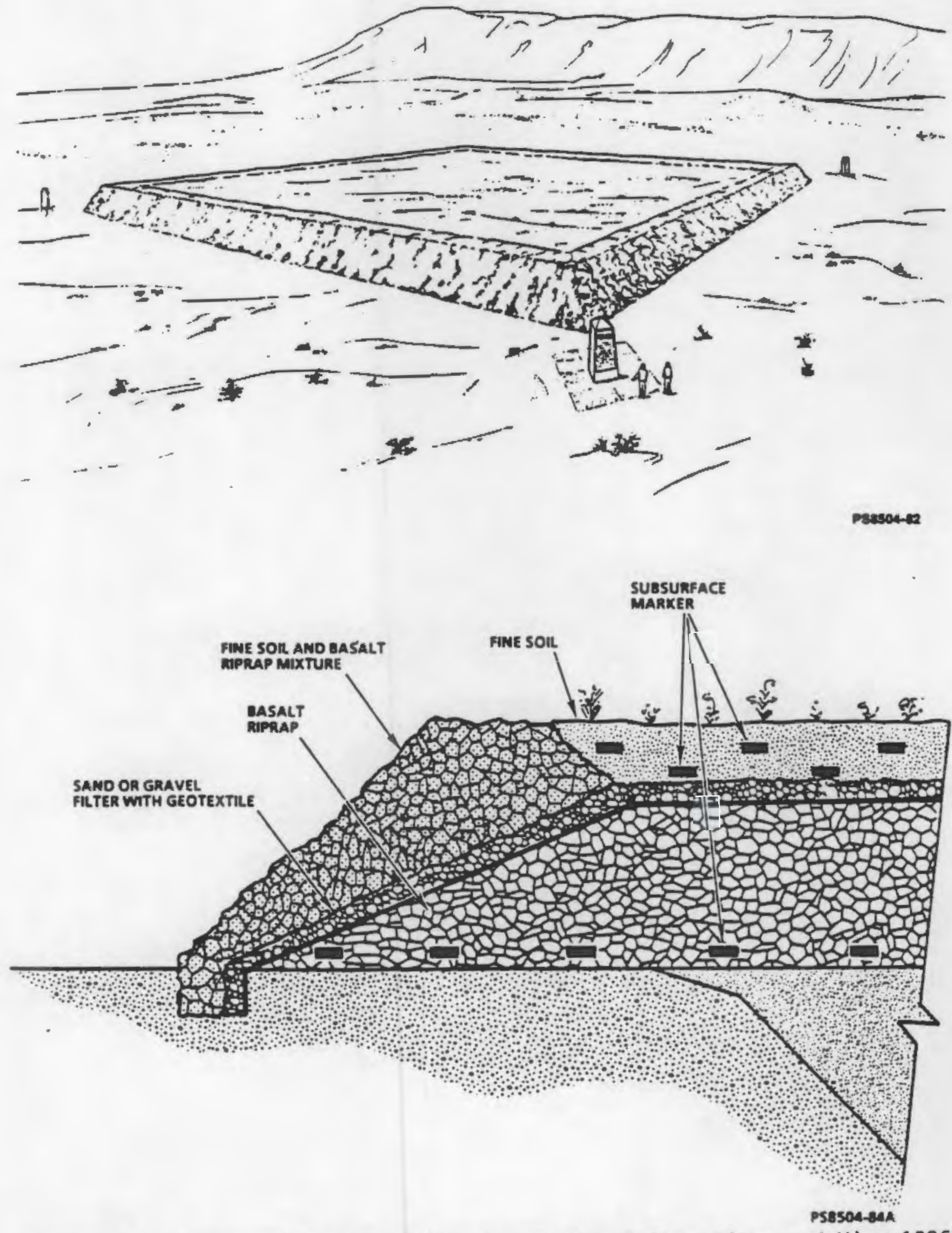

FIGURE 2. Conceptual Design of Barrier System (after Adams and Wing 1986) 



\subsection{TASK OBJECTIVES AND SCOPE}

The purpose of the barrier soil-erosion task is to test performance of the barrier design components as they are affected by water erosion and develop design criteria to reduce the erosion potential. The performance testing and design criteria development will be accomplished primarily through field testing barrier components. The key components involved are the $1.5 \mathrm{~m}$ of McGee Ranch soil, vegetation and rock mulch of the top surface, and the rock-protected side slopes. The erosive processes acting to degrade barrier mounds consist of rainsplash, sheetwash, rilling, gullying, and slumping. Engineered and nonengineered (i.e., environmental) variables that must be considered when evaluating barrier performance include barrier surface slopes, soil characteristics, vegetation cover, rainfall characteristics, and post-construction modifications to the barrier surface.

In addition to the field tests, numerical models that simulate erosion and soil loss will be evaluated for possible use in barrier design. One of the functions of the erosion task is to determine the most stable combination of characteristics to achieve adequate barrier performance for up to 10,000 years.

Models will assist in optimizing these characteristics through evaluation of design variations of the effects of barrier surface slopes, soil characteristics, and vegetation cover. 
: $-$ 


\subsection{PROCESSES AFFECTING BARRIER STABILITY}

The important erosional processes identified to date include rainsplash; overland runoff causing sheetwash, rilling, and gullying on barrier top surfaces; and slumping and gullying of the rock-covered side slopes. Another process that leads to serious erosion of earthen mounds is the settlement and consolidation of the foundation soils or the structure soils. This process is not caused by erosion but does introduce deformations of the soil surface (e.g., barrier top surface) that can accelerate erosion. A suite of parameters and variables governs each process.

\subsection{RUNOFF-EROSION PROCESSES}

\subsubsection{Rainsplash}

Rainsplash is the disaggregation and transport of sediment particles caused by the energy of raindrop impact, and is the major process initiating soil erosion (Dunne and Leopold 1978). Sediment may be bounced into the air and picked up by the wind, or fall into water running over the surface and be transported downslope. The amount of sediment disaggregated by rainsplash is a function of the raindrop diameter, the sediment particle size, cohesion of the sediment, and the slope of the ground surface. Because sloped surfaces composed of silt and sand and devoid of vegetation are most affected by this process, the magnitude of rainsplash erosion on barrier surfaces must be investigated.

\subsubsection{Overland Runoff}

Surface overland runoff ensues when the infiltration capacity of the soil is exceeded by rainfall intensity, or as snow cover is melted rapidly. Water may run off as an irregular sheet or as channelized flow. The erosional processes associated with these types of runoff are termed sheetwash and rilling/gullying, respectively. The amount of sediment lost through these processes is a function of the ground surface gradient and slope length, the discharge of runoff and depth of flow, and sediment particle size and density. Sheetwash is the erosion of thin layers of surface material by continuous sheets of running water. It generally operates with rainsplash, significantly contributing to overall surface lowering. For example, 
unrilled slopes in semiarid Kenya, which have a grade of only $2 \%$, have been lowered $60 \mathrm{~cm}$ in the past 50 years (Dunne and Leopold 1978). Rilling is the formation of closely spaced rills, or runnels, caused by removal of surface soil by streamlets of running water. Erosion by rilling or gullying is more rapid, although more localized, and could result in breaching of the barrier in a single high-intensity event. Therefore, these processes, and the parameters governing them, are important to a complete assessment of barrier stability.

\subsection{PROCESSES SPECIFIC TO ROCK-ARMOREO SIDE SLOPES}

Protecting the side slopes against long-term erosion requires the application of surface armoring to prevent severe overland erosion and the formation of gullies. The use of rock riprap is the approach proposed for the barrier side slopes. The barrier model of Adams and Wing (1986) proposes the use of a combination of rock (basalt) and fine soil for side slope protection.

Slumping and gullying under the rock cover are the important erosional processes on side slopes because the rock cover inhibits rainsplash, sheetwash, or gullying. Other effects of rock cover are to enhance infiltration of moisture in the barrier, and the ensuing extra weight, increased hydrostatic pressures, and reduction of shear strength can lead to slumping and breaching of the barrier. Important parameters in this process include the amount of moisture, the angle of slope, and the bulk density and cohesion of the soil. Unless the proper graded filter layers are placed under the riprap, gullying under the rock cover is also possible because of the steep side slopes (about $\mathrm{IV}: 3 \mathrm{H}$ ). Tendencies for slumping and sub-riprap gullying to occur, and the conditions promoting their occurrence, must all be evaluated using field tests of simulated barrier side slopes.

\subsection{EFFECTS OF SETTLEMENT ON BARR1ER EROSION}

When a soil is loaded by a structure such as an earthen berm, deformations will occur. The total vertical deformation at the soil surface is called settlement. In the case of the barrier mounds this vertical 
displacement can also occur from the settlement of the buried waste packages as well as by consolidation of site and barrier soils.

When a soil is loaded, it will compress because of deformation of the soil grains, compression of air and water in the voids, and/or squeezing out of water and air from the voids. Because the compression of soil grains and pore fluid is very small, it is usually the least important consideration. Therefore, squeezing out of water and air from voids contributes the most to volume change of the loaded soil (Holtz and Kovacs 1981). As the pore fluid is squeezed out, the soil grains rearrange themselves into a more stable, denser configuration, and a decrease in volume and surface settlement results. The amount of rearrangement and compression that takes place depends on the rigidity of the soil skeleton, which is a function of the soil particle shape and structure. In the case of sands or very sandy soils, deformations take place in a very short time because of the relatively high permeability of granular soils (rapid dewatering). Both water and air in the voids can be squeezed out easily. Soils containing clays and silts deform much more slowly because of their relatively low permeability (slow dewatering) and the time it takes the platy clay-mineral particles to change structure from random orientations (flocculated) to aligned. Deformation may continue for as long as decades.

\subsubsection{Differential Settlement}

The use of earthen barriers at Hanford will involve both sandy soil and soil with high silt content including some percentage of clay. Deformations can be expected over the long term for the Hanford barriers, and a certain amount of this can be accommodated in barrier design. However, another problem can occur when the areas of the barrier foundation settle at different rates. This is called differential settlement and can cause a vertical shear failure within the earthen mound. The usual effect of differential settlement is cracking and vertical displacement of the soil surface and is quite common for earthen mounds (e.g., levees, highway berms, mine tailings). The Hanford barriers will be placed over shallow-buried waste sites consisting of materials, such as cardboard boxes, that can both easily compress and degrade, compounding the settlement problem. 
Under this task we are concerned with the effects of overall settlement or differential settlement on barrier soil erosion. The surface discontinuities resulting from settlement can accelerate erosion and lead to channeling of the barrier surface. Any cracking will also increase infiltration into the barrier. 


\subsection{TECHNICAL APPROACH}

To meet the objectives of the Protective Barriers Progran and provide adequate barrier design criteria requires a multifaceted technical approach. Important technical components include a comprehensive literature review, experimental field testing, and modeling of erosional processes acting on the barriers. The literature review is intended to identify important runofferosion processes and parameters from past and ongoing field and laboratory experiments, as well as to acquire and evaluate numerical models that have been recently developed to simulate soil erosion and predict sediment yields. Field experiments will test dominant erosional processes on the barrier's configuration (top surface and side slopes) and soils. For example, the performance of soil from McGee Ranch will be rated under a variety of meteorological conditions. Numerical modeling will be used to predict the response (sensitivity) of the top surface and side slopes to erosive processes and to aid in development of criteria for design of stable barriers. These activities are not exclusive and will be conducted simultaneously. A brief summary of conventional numerical modeling approaches is presented in the appendix.

\subsection{EXPERIMENTAL FIELD TESTING}

The erosion of protective barriers at Hanford will be the result of several complex interactions between processes and barrier components. The effectiveness of rainsplash, sheetwash, gullying, and slumping to degrade barrier surfaces depends on the nature of a rainstorm, the nature of the surface on which the precipitation falls, and the capacity of that surface to resist erosion. Important storm characteristics include storm intensity, duration, timing, and drop size. Surface attributes consist of slope length or surface size, slope gradient, surface microtopography, soil structural and textural characteristics, clay presence and mineralogy, and initial moisture. The ability of the surface to resist erosion is enhanced by the presence of vegetation, cohesion of the soil, and the presence of larger particles (gravel admix and rock mulch). 
A series of field tests is necessary to isolate specific behavioral aspects of the McGee Ranch soil, under certain hydrologic stresses, in view of the large number of interacting components. Running several tests will also allow the task to isolate various barrier design attributes for performance evaluation. Initial tests performed in FY 1989 consisted of rainfall simulations on small flumes, and are designed to measure the interactions of a two-component system composed of storms and McGee Ranch soil. Some of the plots included a gravel admix in the McGee Ranch soil. The results will be reported in FY 1990. Field tests in subsequent years will be conducted on longer plots and will incorporate the added complexities of vegetation, settlement deformations, and other attributes identified in the first year's tests and from the literature review. Plots testing sideslope stability and differential settlement will be designed in FY 1990 and testing begun in FY 1991.

\subsubsection{McGee Ranch Soils}

McGee Ranch soil characteristics were analyzed by Last et al. (1987) at the same time the areal extent of fine sediment was determined. The soil, which consists mostly of silt, was deemed suitable for barriers because the high silt content yields a high moisture-retention capacity. However, during textural analysis, all particles smaller than $0.053 \mathrm{~mm}$ were washed down the drain, thereby excluding a considerable range of silt and clay sizes from the analysis. [The size range for silt is 0.062 to $0.004 \mathrm{~mm}$ and $<0.004 \mathrm{~mm}$ for clay (Simons and Senturk 1977).] Neither the proportion of silt to clay nor the clay mineralogy was determined.

The particle-size information that was lost is significant to barrier performance in terms of overland flow and erosion. Sediment textural characteristics in general, and silt and clay content in particular influence the infiltration capacity and rate, formation of soil glaze and runoff before saturation, erosion from rainsplash, surface shrink and swell and the formation of desiccation cracks, the type of vegetation that may be expected to flourish, and the shape and extent of rills and gullies.

A preliminary field reconnaissance of the soil at McGee Ranch indicates that the soil forms hexagonal desiccation cracks with a hard upper surface. This upper crust could substantially reduce infiltration, except perhaps 
along cracks, and induce runoff before complete saturation of soil. Where the crust was destroyed, primarily along roads, the soil had the texture and consistency of flour. Under these conditions, erosion from rainsplash would prevail and may be substantial. One field investigation occurred after a rather intense local rainstorm at Hanford. Evidence of raindrop impact was apparent from the dimpled surface of the soil near abandoned roads at the McGee Ranch site.

Complete characterization of McGee Ranch soil is critical to assessing barrier performance and the ability of the fine soil to withstand erosion. Complete characterization includes textural (particle-size) analysis and textural variability, the amount and type of clay present in the soil, and the structural response of the soil (e.g., crusting, dimpling, and cracking) to the application of moisture. These properties were observed during the initial fieldwork in FY 1989, and samples were taken for further testing. Particle-size analyses and $x$-ray diffraction of clays will be performed during the second year, before the inception of second-year field studies. These analyses will establish baseline information with which to postulate the response of the soil to precipitation events, and hypothesize evolution of the barrier surface.

\subsection{SITE LOCATION AND TEST EQUIPMENT}

During FY 1989, test runoff-erosion plots were constructed at McGee Ranch, located within the boundaries of the Hanford Site (see Figure 1). Runoff was trapped through the use of galvanized sheet-metal flumes, previously used on the Hanford Site's Arid Lands Ecology (ALE) Reserve for infiltration studies. The plots will be located adjacent to the water tank currentiy in use for other Protective Barriers Program plot studies. Water is supplied by the McGee Ranch well.

Precipitation is applied to the plots by a rotating-boon rainfall simualtor. The simulator is mobile and can be easily moved between plot locations. It uses ten 7.8-m-long booms in a radial configuration that supports a total of 30 nozzles. The nozzles are spaced $1.6 \mathrm{~m}$ along the booms oriented directly at the ground surface. Simulated rainfall intensities of 60 and $120 \mathrm{~mm} / \mathrm{h}$ are obtained by operating 15 or 30 nozzles. The 
nozzles spray downward from $2.5 \mathrm{~m}$ above the ground producing drop-size distributions similar to those of natural rainfall with near terminal velocities after $2.5 \mathrm{~m}$ of free fall (Swanson 1965). Control of rainfall intensity is obtained by control of the water supply pressure. Raindrop sizes can be varied by changing nozzles.

\subsection{FIRST-YEAR FIELD EXPERIMENTS (FY 1989)}

The initial field tests investigated the basic response of McGee Ranch soils to a series of intense rainfall events using an oversimplified twocomponent system consisting of the soils and applied rainfall. In this twocomponent system, soil texture, structure, and mineralogy control the processes of infiltration, moisture retention, and erosion. The tests were designed to characterize the behavior of soil with regard to these processes before adding the more complex components--vegetation, animals, microrelief, varying gradients, and slope length.

The experiments were designed to test two working hypotheses concerning the behavior of the two-component system. The first hypothes is is that in very dry, fine-grained soil (such as that found at McGee Ranch), runoff (overland flow) will commence before complete saturation in response to a number of factors. Fine-grained sediment has a low hydraulic conductivity; only a few millimeters of soil need to be saturated before its water transmission and/or infiltration capacity is exceeded. In addition, fine sediment has a tendency to be self-sealing, which may further reduce its infiltration capacity and promote runoff.

The second hypothesis is that rainsplash is an important erosional process in this two-component system. Silt- and sand-sized particles, the sizes that predominate in McGee Ranch soil (Last et al. 1987), are most easily splashed (Dunne and Leopold 1978). McGee Ranch soil lacks the high organic or clay content that inhibits splash erosion by promoting cohesion. We postulate that rainsplash may be the dominant erosional process if the rainfall intensity of storms is less than the infiltration capacity of the soil, if a crust or glaze does not form, and if soil particles remain disaggregated (i.e., little to no cohesion and no capillary tension). 


\subsubsection{Experimental Design}

To test the hypotheses and gain a working knowledge of the behavior of the simplified soil-rainfall system, test plots with three different soil compositions were subjected to precipitation events generated by the rainfall simulator. One plot consisted of McGee Ranch soil that was excavated, mixed, and returned to the plot without further modifications; this treatment simulated the type of activities (i.e., excavation and mixing) that may occur during barrier construction. A second plot was composed of McGee Ranch soil with a $30 \%$ (by volume) gravel admix incorporated into the top $20 \mathrm{~cm}$ of the plot. The gravel simulated the use of a rock mulch, intended to inhibit erosion on barrier surfaces. A third plot consisted of McGee Ranch soil with additional silt (20\% to $30 \%$ by volume) incorporated into the top $20 \mathrm{~cm}$ of the plot. The silt treatment was intended to simulate potential textural variability encountered as the McGee Ranch soil is mined, as well as give information concerning the formation of soil crusts. To standardize the results and observations of soil behavior generated during testing, the three different soil treatments and precipitation events were replicated four times (Figure 3 ).

To construct each test plot, soil was excavated to a depth of approximately $1 \mathrm{~m}$ in an area measuring $1.4 \mathrm{~m} \times 1.4 \mathrm{~m}$. The soil was mixed during excavation near each hole, where it was moistened and mixed by hand before refilling the holes. The holes were refilled and hand tamped to a uniform bulk density approaching $1.6 \mathrm{~g} / \mathrm{cm}^{3}$ (Figure 4). Following every $20 \mathrm{~cm}$ of fill, the soil was tested with a nuclear test gage and approximately 30 to 50 $g$ of soil taken for moisture and particle size analyses. The additional gravel and silt were tilled into the soil to a depth of approximately $20 \mathrm{~cm}$ with a hand-operated rototiller and hand-tamped to the specified bulk density. The 20- $\mathrm{cm}$ depth is assumed to be sufficient for characterizing the surface interactions between rainfall and sediment.

The plots were submitted to storms of varying intensities (including variations in timing of different intensities throughout the course of a single storm), durations, and drop sizes. The storms were developed from intensity/duration/drop-size data from the literature and pre-test calibration runs with the rainfall simulator. 

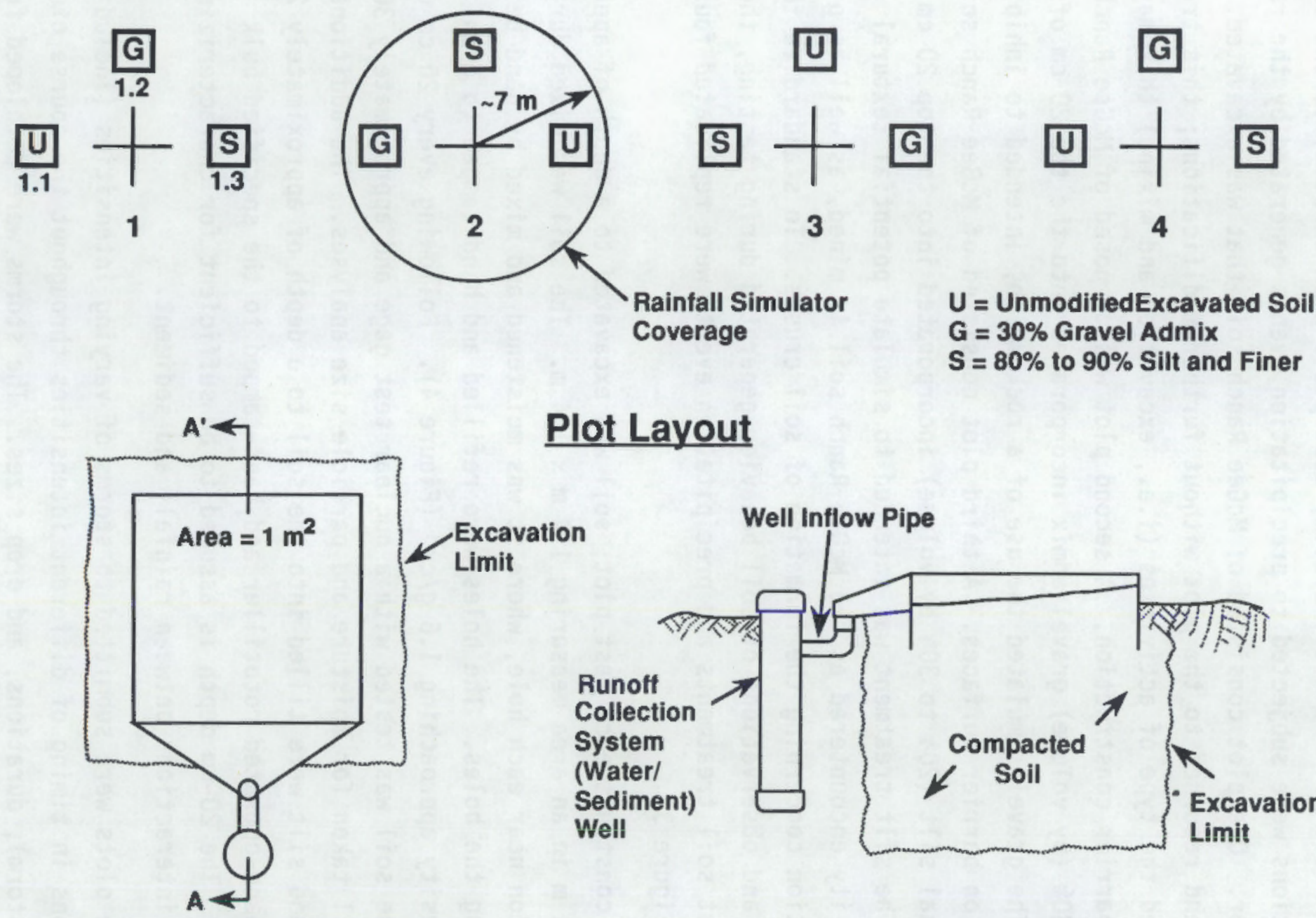

Plan Vlew - Typical Plot Flume

Plot Layout

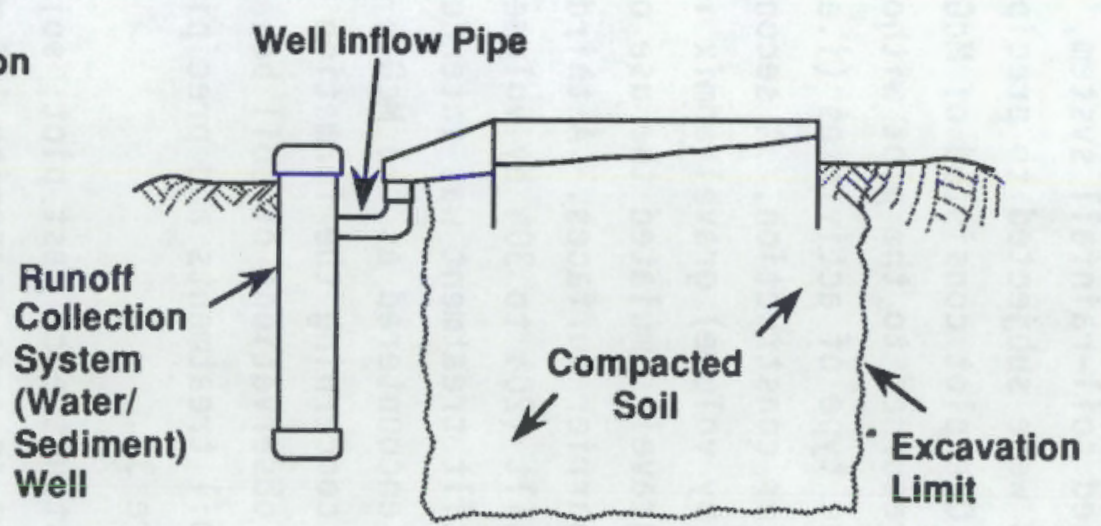

Section A - A'

58907081.1

FIGURE 3. Plot Layout Configulation and Typical Plot Design 


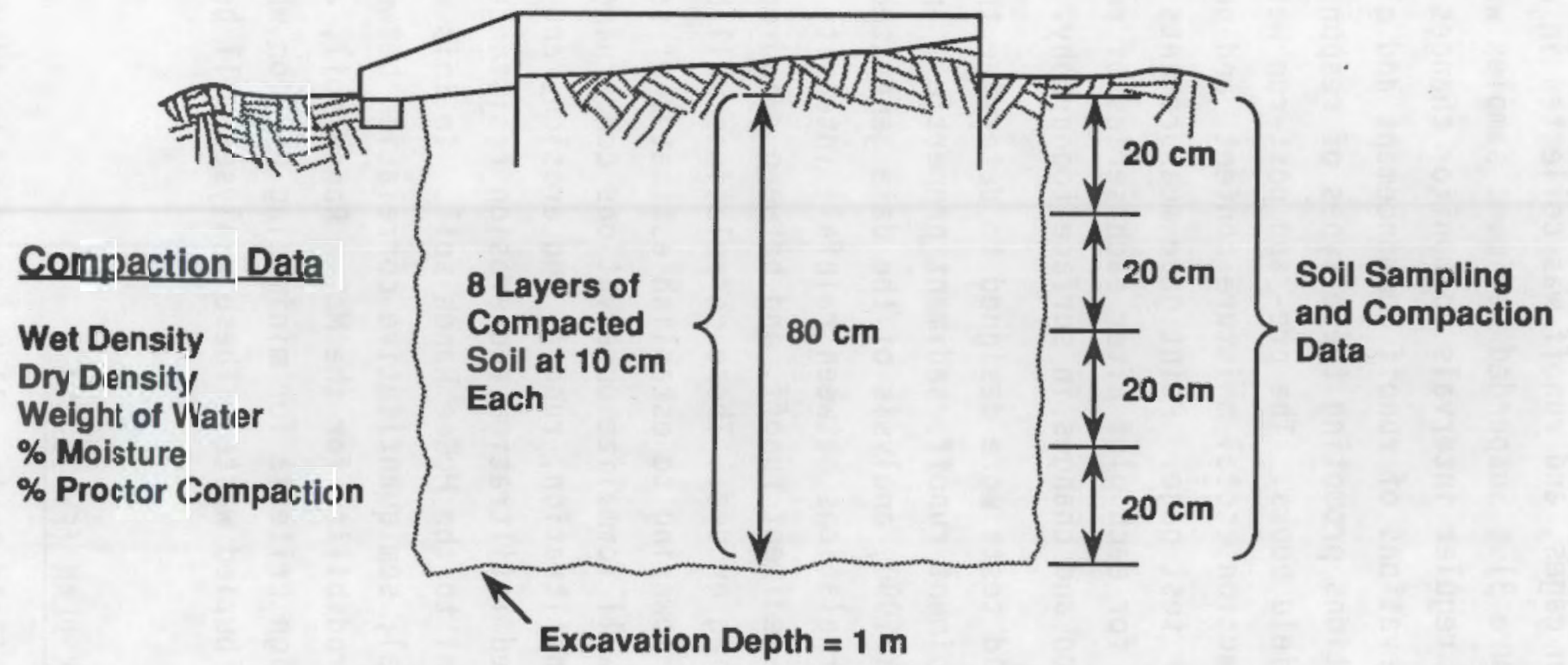

FIGURE 4. Plot Soil Compaction Scheme 
For the most part, these tests provided descriptive, qualitative data as opposed to quantifications of parameters for models. The rainfall amounts were measured by rain gages, and runoff was collected in wells attached to the plot flumes (Figure 3 ). Suspended sediment samples were collected at well inflow pipes at regular intervals to monitor changes in runoff water sediment load. Observations of runoff commencement and glaze formation were noted, and the conditions promoting these types of responses to rainfall were documented in field books. The pre- and post-run wet and dry densities, percent Proctor compaction, total moisture content, and percent moisture were measured by a nuclear test gage. Point gage measurements were taken at three cross sections for each plot after each series of runs to estimate the amount of soil erosion and changes in surface topography.

The FY 1989 field tests were designed to determine the relationships between water and sediment runoff, sediment properties, and storm characteristics. During FY 1990, analysis of the data generated by the tests will seek to establish correlations between rainfall intensity and the timing and amounts of water and sediment runoff, and between raindrop sizes and the sizes of sediment being eroded. These correlations will be compared with gaged ground-surface lowering to establish estimates of sediment yields from the test plots. We will formalize observations concerning surface sealing and its effects on infiltration, runoff, and erosion, and assess the potential for enhanced infiltration and erosion resistance generated by the addition of pea gravel to the McGee Ranch soil. In this way, we will establish a conceptual, semiquantitative correlation between rainfall erosivity and soil erodibility for the McGee Ranch soil, and begin to evaluate barrier design criteria for minimizing erosion while diverting runoff away from the buried waste. These analyses will be reported in the FY 1990 status report.

\subsection{SECOND-YEAR WORK PLAN (FY 1990)}

The second-year field tests will be designed based on the results of the first-year's testing, plus the need to add complexities to our oversimplified (and unrealistic) system. Field plots will be larger in area and fewer in 
number. Larger plots are necessary because actual barriers will be many times larger than the first-year's test plots $\left(1 \mathrm{~m}^{2}\right)$, and have much greater areas that contribute to storm runoff. Greater contributing areas yield potentially deeper flows and potentially greater erosion, possibly expressed as localized breaching of the barrier top surface. Fewer, but larger, plots are proposed for FY 1990. Slope gradients will be kept constant at about $1 \mathrm{~V}: 50 \mathrm{H}$.

During the second year of testing, plot soil treatments will be limited to two, namely unmodified McGee Ranch soil and soil with an addition of up to 30\% gravel admix (rock mulch). Testing conducted during previous years in other tasks revealed that the incorporation of rock mulch does not increase infiltration, does not adversely affect vegetation growth, and increases resistance to wind erosion. During the second year of tests we will assess the utility of rock mulch for inhibiting water erosion on longer plots and compare the results to observations and measurements of the types and amounts of erosion generated on unmodified soil plots.

The effects of vegetation as an erosion inhibitor will also be addressed during the second year of tests, but more in a planning capacity than in actual measurements. Plot preparation requires disturbance of the ground surface to a depth of $20 \mathrm{~cm}$, thereby disrupting existing vegetation, to incorporate the rock mulch as well as to simulate barrier construction. Native vegetation will be seeded on the plots before soil compaction. Rainfall-runoff tests will be performed on the seeded (but bare) plots during FY 1990. These tests will simulate barrier conditions immediately after construction, or in the event of a fire. If the seeds are not dislodged, vegetation should be sufficiently established on the plots so that its effects may be addressed during test runs in FY 1991 . We expect that the overall effect of the vegetation will be to reduce runoff and erosion by enhancing infiltration and intercepting the raindrops that may cause rainsplash erosion.

Before the inception of the second year's field tests, field equipment, instruments, and plot design will be re-evaluated as to their usefulness in generating representative data, based on the results of the first-year's tests. Alternative precipitation application systems will be explored. 
Instruments will be overhauled and recalibrated, if necessary. Field test plots may be redesigned if the results of the first-year's tests indicate that the flume apparatus used imposed artificial boundary conditions that significantly skewed the runoff and erosion data.

A pilot study of side slope erosion will be designed based on a literature review. He anticipate using a 1/3-scale version of barrier side slopes for the initial investigations of the effects of rainfall on the fine soil and basalt riprap mixture. The actual testing of side-slope erosion will be conducted during FY 1991 .

A literature review of available numerical models that simulate soil erosion and predict sediment yields will be conducted. Initial testing of the models using field plot data and theoretical test data will commence in FY 1990. The initial testing with models will be used to determine senstivity of the barrier soil surfaces to erosive processes.

\subsection{WORK PROPOSED FOR OUTYEARS (FY 1991 - 1993)}

Field tests proposed for FY 1991 will include increasing the number of system complexities with which to evaluate the ability of the barrier surfaces to resist erosion. The effects of vegetation and possibly animal burrowing on runoff and erosion will be tested through the application of artificial precipitation on the field plots prepared for FY 1990 tests. Longer test plots will be established in an effort to begin realistic empirical quantification of runoff and sediment loss from surfaces approaching actual barrier dimensions. Accurate quantification of these parameters is essential for a number of reasons. The biointrusion and water infiltration control tasks require approximate volumes of runoff that can be expected from a range of meteorologic events to fully evaluate the impacts of runoff interception and deep penetration. Our own task requires quantification of runoff from barrier top surfaces to assess the impacts of these volumes of water on barrier side slopes, the testing of which will begin in FY 1991. The design of field tests to study the effects of differential settlement will commence, and the evaluation of numerical models will continue. 
Work planned for FY 1992 includes development of final fieid test designs based on results from the previous years' field tests. Actual testing will begin in FY 1992 and be completed during FY 1993. The numerical modeling work will be completed in FY 1990, and a final decision on model applicability and selection of a modeling scheme to assist in designing the barriers will be made.

Field studies begun in and before FY 1992 will be completed in early FY 1993 to provide sufficient time for data analysis. Overall recommendations of barrier design criteria will be generated and final reports prepared.

\subsection{SCHEDULE AND ESTIMATED COSTS}

The scheduled yearly tasks and costs (Table 1) are based on current projected needs of the barrier program. These needs may be revised as the work progresses and each year's data are analyzed. Our decision was to comance field testing with a simple two-component system (McGee Ranch soil and applied rainfall) before constructing the larger plots and adding complexities (e.g., vegetation, animal burrowing). This allowed us to use available flumes and equipment, which conserved funds and expedited the field work. During the following years (FY 1990 to FY 1993), material will be purchased to construct the larger flumes and other test plots.

The cost estimates include only staff time (including support staff), graphics, report preparation, and materials. Capital equipment needs have not been identified to date and are not included. Material requirements may vary based on the success of the proposed field tests and will need to be reviewed annually. 
TABLE 1. Schedule and Costs Per Fiscal Year

Task Sumunary

Literature Review

Design/Prepare Test Plots

Calibrate Rainfall Simulator

Conduct Field Tests

Status Report

Literature Review (continued)

Design/Prepare Larger Plots

Conduct Field Tests

Numerical Model Review

Design Side Slope Tests

Status Report

Literature Review (continued)

Large Plot Test (continued)

Conduct Side Slope Tests

Design Settlement/Burrowing Tests

Evaluate Numerical Models

Status Report

Design Final Field Tests

Commence Final Field Tests

Select Models to be Applied

Status Report

Complete Field Testing

Final Data Analysis

Develop Design Recommendations

Final Report
Year

FY 1989 (a)

FY 1990

210.0

FY 1991

$475.0(b)$

FY 1992

$400.0(b)$

FY 1993

$200.0(b)$

(a) FY 1989 work has been completed.

(b) Estimated.

$\overline{\$ 1,455.0}$ 


\subsection{SAFETY AND QUALITY ASSURANCE}

Before initiating laboratory or fieldwork, a preliminary safety review and risk assessment will be completed. Subjects to be addressed in the review include site, material, radiation, and personnel safety. Standard PNL safety procedures will be applied to any potential safety risks identified in the review and to all office, laboratory, and fieldwork associated with the risk.

A quality assurance plan for the Protective Barriers Program, which was issued July 7, 1988, (or a revision to that plan) will be applied to this task. At the initiation of the task, an impact-level assessment will be initiated by the task manager and concurrence obtained through appropriate programmatic and line managenent. The level of quality assurance will guide individual subtasks according to the impact-level assessment and PNL procedures. 


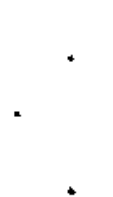




\subsection{REFERENCES}

Adams, M. R. and N. R. Wing. 1986. Protective Barrier and Warning Marker System Development Plan. RHO-RE-PL-35P, Rockwell Hanford Operations, Richland, Washington.

Dunne, T., and L. B. Leopold. 1978. Water in Environmental Planning. W. H. Freeman, San Francisco.

Holtz, R. D., and W. D. Kovacs. 1981. An Introduction to Geotechnical

Engineering. Prentice-Hall Inc., Englewood Cliffs, New Jersey.

Last, G. V., M. A. Glennon, M. A. Young, and G. W. Gee. 1987. Protective Barrier Materials Analysis: Fine Soil Site Characterization. PNL-6314,

Pacific Northwest Laboratory, Richland, Washington.

Simons, D. B., and F. Senturk. 1977. Sediment Transport Technology. Water Resources Publications, Fort Collins, Colorado.

Swanson, N. P. 1965. "Rotating-Boom Rainfall Simulator." Trans. Am. Soc. Agric. Eng. 8(1):71-72. 


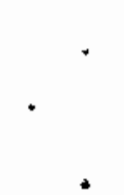

* 


\section{APPENDIX}

NUMERICAL MODELING OF EROSION 
APPENDIX

\section{NUMERICAL MOOELING OF EROSION}

Several models encompassing a broad range of complexity are available to estimate overland flow, erosion, soil loss, and sediment yield on natural and disturbed surfaces. Although the models were developed primarily for application to agricuitural problems, the parameters governing the basic processes are the same, and the models are therefore useful for testing sensitivity to change in individual parameters. Because the models were developed for purposes other than engineered earthen mounds, and because many of the models contain estimated parameters that are suitable only for the data bases from which they were derived, direct application of any of the models to barrier erosion is discouraged until they have been tested with respect to their applicability.

The simplest models for estimating runoff, soil loss and sediment yield are based on regression analyses. Two of the most widely applied models in this category are the Universal Soil Loss Equation (USLE) (Wischmeier and Smith 1978) and the modified Universal Soil Loss Equation (MUSLE) (Williams 1975). The USLE is an empirically derived equation composed of a multiplicative string of factors that is used to predict an average annual soil loss in tons per acre. The factors consist of rainfall erosivity, soil erodibility, hillslope length and gradient, cropping management, and erosion control practice. The MUSLE contains essentially the same factors as the USLE, but sediment yield is computed on a storm-by-storm basis for applicability to the arid western United States.

Neither the USLE nor the MUSLE is well-suited for application to the barrier erosion problem at Hanford. Data bases from which the factors were derived were compiled from conditions existing east of the Rocky Mountains, which could introduce significant errors when applying these models locally. Because these models are not based on a mathematical simulation of the physical processes, the factors must be estimated independently for each climatic scenario. This approach ignores any feedback, threshold effects or 
change in boundary conditions caused by previous conditions. Use of the USLE or MUSLE may lead to gross errors in predictions of soil loss or barrier life. The models may be useful, however, for preliminary evaluation of barrier design criteria or testing the sensitivity of parameters to change.

The alternative to using models based on regression analyses is to use those based on physical process simulations. Several models have been developed and tested, including the Chemicals, Runoff, and Erosion from Agricultural Management Systens model (CREAMS) (Knisel 1980), the Multiple Watershed Water and Sediment Routing model (MULTSED) (Simons et al. 1980), and the expanded Kinematic Runoff model (KINEROS) (Smith 1981). CREAMS is a daily simulation model that estimates runoff, erosion and sediment, and plant nutrient and pesticide yield from field-sized areas. Although CREAMS is primarily physically based, it contains some elements from the USLE. MULTSED was developed to route storm water, estimate soil erosion, and route sediment yield from watersheds with complex geometry by applying the kinematic wave approximation for both overland and channel flow. The XINEROS model uses a similar approach. Each of these models, and any others identified in the course of the literature review, will be evaluated as to their applicability to the problem of barrier erosion.

\section{REFERENCES}

Knisel, W. G., ed. 1980. CREAMS: A Field-Scale Model for Chemicals, Runoff, and Erosion from Agricultural Management Systems. Conservation Research Report No. 26, U.S. Department of Agriculture, Washington, D.C.

Simons, D. B., R. M. Li, and W. T. Fullerton. 1980. User's Manual Multiple Watershed Model for Water and Sediment Rout ing from Mined Areas. Simons, Li and Associates, Ft. Collins, Colorado.

Smith, R. E. 1981. "A Kinematic Model for Surface Mine Sediment Yield." Trans. Am. Soc. Agri. Eng. 24:1508-1514.

Williams, J. R. 1975. "Sediment Yield Prediction with Universal Equation Using Runoff Energy Factor." In Present and Prospective Technology for Predicting Sediment Yields and Sources, Pp. 244-52. ARS-S-40, Agricultural Research Service, U.S. Department of Agriculture, Washington, D.C.

Wischmeier, W. H., and D. D. Smith. 1978. Predicting Rainfall Erosion Losses - A Guide to Conservation Planning. Agriculture Handbook No. 537, U.S. Department of Agriculture, Washington, D.C. 
PNL -6791

UC-403

\section{DISTRIBUTION}

No. of

Copies

OFFSITE

2 Office of Scientific and Technical Information

\section{ONSITE}

6 DOE Richland Operations Office

G. J. Bracken

J. J. Broderick

P. K. Clark

R. D. Freeburg

R. D. Izatt

G. W. Rosenwald

20 Westinghouse Hanford Company

M. R. Adams

L. C. Brown

J. W. Cammann

R. A. Carlson

H. F. Daugherty

W. F. Heine

J. M. Henderson

G. W. Jackson.

K. N. Jordan

D. S. Landeen

R. E. Lerch

H. E. McGuire

K. W. Owens

K. L. Petersen

S. J. Phillips .

J. F. Relyea

R. C. Roos

D. D. Wodrich

R. D. Wojtasek

D. E. Wood
No. of

Copies

38 Pacific Northwest Laboratory

L. L. Cadwell (4)

M. D. Campbell

R. M. Ecker

J. W. Falco

M. J. Fayer

M. G. Foley

H. D. Freeman

G. W. Gee (2)

J. M. Hales

P. C. Hays

K. A. Hoover (4)

C. T. Kincaid

R. R. Kirkham

M. W. Ligotke

S. 0 . Link

W. T. Pennell

L. E. Rogers

R. L. Skaggs

J. M. Thomas

W. H. Walters (4)

Publishing Coordination

Technical Report files 
